\title{
Soil Properties, Okra Performance and Nutrient Compositions as Affected by Tillage and Maize Cob Ash
}

\author{
Aruna Olasekan Adekiya1*, Taiwo Michael Agbede2, Christopher Muyiwa Aboyeji1, Kehinde Abodunde Adegbite1, \\ Oluwagbenga Dunsin1, Timothy A. Adekanye1, Charity O. Aremu1 \\ ${ }^{1}$ College of Agricultural Sciences, Landmark University, P. M. B. 1001, Omu-Aran, Kwara State, Nigeria \\ ${ }^{2}$ Department of Crop, Soil and Pest Management Technology, Rufus Giwa Polytechnic, P.M.B. 1019, Owo, Ondo State, Nigeria
}

Received: January 14, 2019 / Revised: January 29, 2019 / Accepted: February 02, 2019

(C) Korean Society of Crop Science and Springer 2019

\begin{abstract}
Alfisols, the dominant soil order in southwest Nigeria in which crops are grown possess unfavorable peculiarities such as low inherent fertility and acidity. These limitations can be ameliorated by tillage and organic manuring. Therefore, field experiments were conducted during the 2014 and 2015 cropping seasons to assess the effects of tillage methods and maize cob ash (MCA) on soil properties, yield, growth, mineral, and vitamin $\mathrm{C}$ contents of okra fruit. The experiment consisted of 3 $\times 3$ factorial combinations of three tillage methods \{zero - tillage ZT, manual ridging MR, and plowing plus harrowing $\mathrm{P}+\mathrm{H}\}$ and three rates $\left(0.0,3.0\right.$, and $\left.6.0 \mathrm{t} \mathrm{ha}^{-1}\right)$ of application of MCA. Tillage methods and MCA influenced soil physical and chemical properties, performance, mineral and vitamin $\mathrm{C}$ contents of okra fruit significantly. $\mathrm{MCA}$ increased soil K, Ca, Mg, okra yield, growth, mineral and vitamin $\mathrm{C}$ contents of okra fruits up to $3 \mathrm{t} \mathrm{ha}^{-1}$ level after which there was a decrease. The order of reducing bulk density and soil chemical properties, increasing porosity, yield, growth, mineral and vitamin $\mathrm{C}$ contents of okra was: $\mathrm{ZT}>\mathrm{MR}>\mathrm{P}+\mathrm{H}$. Tillage appears to be indispensable for sustainable okra production on Alfisol of southwest Nigeria. Growth and yield of okra in this study was dependent on soil physical properties and chemical properties such as $\mathrm{pH}, \mathrm{OM}, \mathrm{N}$, and $\mathrm{K}$. Combination of $\mathrm{P}+\mathrm{H}$ and $3 \mathrm{t} \mathrm{ha}^{-1} \mathrm{MCA}$ produced better yield, growth, mineral and vitamin $\mathrm{C}$ contents of okra compared with other combinations of tillage with MCA. Addition of MCA to either $\mathrm{P}+\mathrm{H}$ or $\mathrm{MR}$ is important to reduce the limitation of acidity associated with tropical Alfisol.
\end{abstract}

Key words : Tillage, maize cob ash, Alfisol, okra, vitamin C, bulk density, porosity

\section{Introduction}

Okra (Abelmoschus esculentus. L. Moench) is an important fruit vegetable crop grown worldwide. Okra is one of the most widely known and utilized species of the family Malvaceae (Naveed et al. 2009). Okra is a multipurpose crop due to its various uses of the fresh leaves, bud, flowers, pods, stems, and seeds (Minhretu et al. 2014). Okra immature fruits, which are consumed as vegetables can be used in salads, soups, and stews, fresh or dried, fried or boiled (Ndunduru and Rajabu 2004). According to Chrito and Onuh (2005), okra fruit contains $86 \%$ water, $2.2 \%$ protein, $10 \%$ carbohydrate, $0.2 \%$ fat, and vitamins A, B, and C. Okra seeds are a source of oil and protein. The seeds have been used on a small scale for oil production (Gemede et al. 2014). It can also be used as

Aruna Olasekan Adekiya ( $\triangle)$

Email: adekiya2009@yahoo.com non-caffeinated substitute for coffee. Okra seeds may be roasted and ground to form a caffeine-free substitute for coffee (Calisir and Yildizi 2005).

Despite the numerous potentials of okra fruit production, it level of production and yield per hectare has been very low in Nigeria (about 2.7 $\mathrm{M} \mathrm{tha}^{-1}$ ) compared with India (10.5 $\mathrm{M} \mathrm{t}$ $\left.\mathrm{ha}^{-1}\right)$, Sudan (10.2 $\mathrm{M} \mathrm{tha}^{-1}$ ), Egypt (15.7 $\mathrm{M} \mathrm{tha}^{-1}$ ), and Saudi Arabia (11.5 $\mathrm{M} \mathrm{tha}^{-1}$ ) according to Varmudy (2011). Among the many factors responsible for low yield is the low fertility status of most soils in the growing areas.

Tillage and the use of organic manures are important agronomic practices that can sustain soil fertility and high crop yield (Adekiya, et al. 2016). Tillage operations are known to influence both the release and conservation of nutrients. Tillage practices modify the soil structure by chang- 
ing physical properties such as soil bulk density, soil porosity, and moisture contents. However, intensive or repetitive tillage causes rapid degradation of soil physical, chemical, and biological qualities especially in the case of Alfisol of southwest Nigeria (Adekiya et al. 2011).

Currently, there is significant interest and emphasis on a shift to the conservation and no-tillage methods for the purpose of controlling erosion, conserving soil and water, mitigating drought, reducing tillage costs, increasing soil organic matter, boosting crop productivity, and reducing net $\mathrm{CO}_{2}$ emissions which contribute to global warming (Agbede 2013). However, for large-scale production of crops, especially okra, the use of mechanized tillage that involved plowing and harrowing is inevitable. There had been no study to compared no-tillage and traditional farmers' manual ridging with mechanized tillage for okra production. Therefore, in this study, there is the need to examine the potential of growing okra using zero-tillage, manual ridging, compared with mechanized plowing and harrowing and their effects on soil fertility and okra performance.

Maize cob ash is the ash gotten from the incineration of maize cob, especially after the grains of maize have been eaten, or otherwise utilized. Studies have established ash as a fertilizing and liming material (Abdulhamid and Mustapha 2009; Adekiya et al. 2018; Ewulo 2009; Owolabi et al. 2003). However, the effect of maize cob ash and tillage on soil properties and okra performance has not received research attention. In southwest Nigeria, the dominant soil order on which crops are grown are the Alfisol which possess unfavorable peculiarities such as low fertility, soil acidity, and physical limitations such as crust formation, compaction, shallow and effective rooting depth (Lal 1986). According to the FAO (1994), these limitations can be rectified by tillage and organic manuring. Therefore, a soil management involving an appropriate tillage method and agro waste like maize cob ash will be affordable, adoptable, and environmentally friendly and sustainable and is expected to enhance and sustain high soil fertility, productivity, and okra yield. Moreover, tillage and organic manuring especially ash may also influence the mineral and vitamin $\mathrm{C}$ composition of crops. This aspect needs to be investigated for okra. Therefore the objective of this study was determined the effect of tillage methods and maize cob ash on soil properties, yield, growth, mineral and vitamin $\mathrm{C}$ contents of okra fruit.

\section{Materials and Methods}

\section{Site description and treatments}

Field experiments were conducted during the 2014 and 2015 cropping seasons at Owo (latitude $7^{\circ} 12^{\prime} \mathrm{N}$, longitude $5^{\circ} 32^{\prime} \mathrm{E}$ ) in the forest-savanna transition zone of southwest Nigeria. The soil at Owo is an Alfisol classified as an Oxic Tropuldalf (USDA 2010) or Luvisol (FAO 1998) derived from quartzite, gneiss, and schist. The top of the soil at the site was sandy loam. There are two rainy seasons, one from
March to July and the other from mid-August to November, with temperatures ranging from 24 to $32^{\circ} \mathrm{C}$. The average rainfall varied from 1240 to $1346 \mathrm{~mm}$. The experimental site had been under bush fallow for 2 years after arable cropping to maize, yam, and cassava. The predominant weeds at the site were Siam weed (Chromolaena odorata L. King and Robinson), water leaf (Talinum triangulare Jacq. Wild) and Guinea grass (Panicum maximum Jacq.). The experiments were conducted to assess the effects of tillage methods and maize cob ash on soil properties, growth, yield, mineral and vitamin $\mathrm{C}$ contents of okra fruit.

The experiment each year consisted of $3 \times 3$ factorial combinations of three tillage methods zero - tillage ZT (manual clearing with a cutlass followed by treatment with paraquat - 1,1-dimethyl 4-4-bipyridilium dichloride - at the rate of $2.5 \mathrm{~kg} \mathrm{ha}^{-1}$ a.i. sprayed 2 weeks before sowing okra seeds on the flat with cutlass in the killed sod without primary or secondary tillage operations), manual ridging MR (the ridge was prepared by heaping the soil surface layer using the traditional hoe after cleared weeds had been removed from the plots) and plowing plus harrowing $\mathrm{P}+\mathrm{H}$ (soil was plowed and harrowed to $0.20 \mathrm{~m}$ depth once using a tractor-mounted disc plow and harrow) $\}$ and three rates $(0.0,3.0$ and $6.0 \mathrm{t}$ $\mathrm{ha}^{-1}$ ) of application of maize cob ash (MCA).

The tractor used was a Steyer 768 and its weight was 4500 $\mathrm{kg}$. There was an initial clearing of the plots before tillage operations for treatments $\mathrm{P}+\mathrm{H}$. The experiment was laid out in a randomized complete block design with three replications. Each plot size was $12 \times 10 \mathrm{~m}$. To minimize interference, blocks were $4 \mathrm{~m}$ apart, and plots were $3 \mathrm{~m}$ apart. The same tillage treatment and maize cob ash rate was allotted to each plot for the 2 years of study.

\section{Crop establishment}

Tillage treatments were carried out in April in both 2014 and 2015. Sowing of okra seeds (variety NHAe-47-4) was done immediately after tillage. Three seeds of okra were sown per hole at inter-row spacing of 0.6 and $0.6 \mathrm{~m}$ intra-row and two weeks after sowing, thinning to one plant per stand was done giving a plant population of 27,778 plants $\mathrm{ha}^{-1}$ and this was followed by manual weeding using hand hoe before application of maize cob ash. MCA used for the experiment was prepared by collecting maize cob from maize farmers, sundried, and burnt into ashes inside a bin. The ash was then sieved to remove pebbles and unburnt shaft. MCA was applied in ring form to the soil 2 weeks after sowing okra seeds at the rates $0.0,3.0$, and $6.0 \mathrm{t} \mathrm{ha}^{-1}$. Subsequent weeding was done manually during the planting season, and insect pest control was carried out using cypermetrin applied at the rate of $30 \mathrm{ml}$ per $10 \mathrm{l}$ of water.

\section{Soil sampling and analysis}

Before the commencement of the experiment in 2014, soil samples were taken from $0-0.15 \mathrm{~m}$ depth at 10 points selected randomly from the experimental site. Soil samples were collected using steel coring tubes $(0.04 \mathrm{~m}$ diameter, 
$0.10 \mathrm{~m}$ high) and were put in an oven set at $100^{\circ} \mathrm{C}$ for $24 \mathrm{~h}$ for the determination of bulk density. The soil samples collected were also bulked, air-dried, and sieved using a 2 $\mathrm{mm}$ sieve and analyzed for particle size, soil organic matter, $\mathrm{N}, \mathrm{P}, \mathrm{K}, \mathrm{Ca}, \mathrm{Mg}$, and $\mathrm{pH}$. Soil samples were also collected at harvest of okra from $0-0.15 \mathrm{~m}$ depth in 2014 and 2015 on an individual plot basis and similarly analyzed for chemical properties. Samples were analyzed as described by Carter (1993). Particle size was analyzed by the hydrometer method (Sheldrick and HangWang 1993). Soil organic carbon was determined by the procedure of Walkley and Black using the dichromate wet oxidation method (Nelson and Sommers 1996). Organic matter was calculated by multiplying $C$ by 1.724. Total $\mathrm{N}$ was determined by the micro-Kjeldahl digestion method (Bremner 1996). Available P was determined by Bray-1 extraction followed by molybdenum blue colorimetry (Frank et al. 1998). Exchangeable $\mathrm{K}, \mathrm{Ca}$, and $\mathrm{Mg}$ were extracted using $1 \mathrm{M}$ ammonium acetate. Thereafter, $\mathrm{K}$ level was determined on a flame photometer, and $\mathrm{Ca}$ and $\mathrm{Mg}$ were determined by EDTA titration (Hendershot et al. 2007). Soil pH was determined using a soil-water medium at a ratio of $1: 2$ with a digital electronic $\mathrm{pH}$ meter.

One month after sowing of okra seeds, determination of certain soil physical properties in all plots commenced and this was done at two-week intervals on four occasions for each year. Six samples ( $0.04 \mathrm{~m}$ diameter, $0.10 \mathrm{~m}$ high) were collected at $0.10 \mathrm{~m}$ depth from each plot using a steel core sampler and were used for the evaluation of bulk density, total porosity, and gravimetric water content after oven-dried at $100^{\circ} \mathrm{C}$ for $24 \mathrm{~h}$. Total porosity was calculated from the values of bulk density and particle density.

\section{Growth and yield observations}

Growth parameters measured were plant height (by the use of meter rule) and leaf area - at mid-flowering was determined by using the model $\left\{\mathrm{LA}=0.34(\mathrm{LW})^{1.12}\right\}$ developed by Omolaiye et al. (2015), where LA = leaf area, $\mathrm{L}=$ leaf length and $\mathrm{W}=$ leaf width. Pods were harvested at 4-day intervals counted and weighed. Pod weight was evaluated based on the cumulative number of pods at eight harvests.

\section{Analysis of maize cob ash and okra fruits}

About $2 \mathrm{~g}$ of the ash used was collected and analysed for $\mathrm{N}, \mathrm{P}, \mathrm{K}, \mathrm{Ca}$, and $\mathrm{Mg}$ as described by Tel and Hagarty (1984). $\mathrm{N}$ was determined by the micro-Kjeldahl digestion method. Samples were digested with nitricperchloric- sulphuric acid mixture for the determination of $\mathrm{P}, \mathrm{K}, \mathrm{Ca}$, and $\mathrm{Mg}$. Phosphorus was determined colorimetrically using the vanadomolybdate method, $\mathrm{K}$ was determined using a flame photometer and $\mathrm{Ca}$ and $\mathrm{Mg}$ were determined by the EDTA titration method (Horwitz and Latimer 2005).

Each year, 10 okra fruits of uniform sizes were randomly collected from each plot and analyzed for mineral contents. Mineral elements of okra fruits were determined according to methods recommended by the Association of Official Analytical Chemists (AOAC 2003). One gram of each sample was digested using $12 \mathrm{~cm}^{-3}$ of the mix of $\mathrm{HNO}_{3}, \mathrm{H}_{2} \mathrm{SO}_{4}$, and $\mathrm{HCLO}_{4}(7: 2: 1 \mathrm{v} / \mathrm{v} / \mathrm{v})$. Contents of $\mathrm{Cu}, \mathrm{Fe}, \mathrm{K}$, and $\mathrm{Ca}$ were determined by atomic absorption spectrophotometry and vitamin $\mathrm{C}$ content was determined by using the indophenol dye method (Singh et al. 2007).

\section{Statistical analysis}

Data collected from each experiment were subjected to analysis of variance (ANOVA) using the Genstat statistical package (GENSTAT 2005) to determine the effects of treatments on soil physical and chemical properties, growth, yield, mineral and vitamin $\mathrm{C}$ contents of okra fruit. The standard error of difference between means (s.e.d.) was used to compare the treatment means. Mention of statistical significance refers to $P=0.05$ unless otherwise stated.

\section{Results}

Table 1 shows the results of the physical and chemical properties of the experimental site and the chemical analysis of the MCA used for the experiment. The soil was sandy loam in texture, high in bulk density, acidic and low in organic matter (OM), total $\mathrm{N}$, exchangeable $\mathrm{K}$ and $\mathrm{Ca}$ and adequate in available $\mathrm{P}$ and exchangeable $\mathrm{Mg}$ according to the critical levels of $3.0 \% \mathrm{OM}, 0.2 \%$ total $\mathrm{N}, 10.0 \mathrm{mg} \mathrm{kg}^{-1}$ available $\mathrm{P}, 0.16-0.20 \mathrm{cmol} \mathrm{kg}^{-1}$ exchangeable $\mathrm{K}, 2.0 \mathrm{cmol}$ $\mathrm{kg}^{-1}$ exchangeable $\mathrm{Ca}$, and $0.40 \mathrm{cmol} \mathrm{kg}^{-1}$ exchangeable $\mathrm{Mg}$ recommended for crop production in ecological zone of Nigeria (Akinrinde and Obigbesan 2000). Analysis of MCA showed that the $\mathrm{pH}$ was very strongly alkaline and it also contained high level of $\mathrm{K}, \mathrm{Ca}, \mathrm{Mg}$, and trace values of $\mathrm{N}$ and $\mathrm{P}$.

\section{Changes in soil properties}

The effect of soil physical properties on year, tillage

Table 1. Soil properties before experimentation and nutrient contents of maize cob ash used for the study.

\begin{tabular}{lcc}
\hline \multicolumn{1}{c}{ Property } & Soil values & Maize cob ash values \\
\hline Sand (\%) & 69 & $\mathrm{nd}$ \\
Silt (\%) & 17 & $\mathrm{nd}$ \\
Clay (\%) & 14 & $\mathrm{nd}$ \\
Textural class & Sandy loam & $\mathrm{nd}$ \\
Bulk density $\left(\mathrm{Mg} \mathrm{m}^{-3}\right)$ & 1.46 & $\mathrm{nd}$ \\
$\mathrm{pH}($ water) & 5.56 & 11.1 \\
Organic matter (\%) & 2.81 & $\mathrm{nd}$ \\
Total N (\%) & 0.19 & 0.16 \\
Available P $\left(\mathrm{mg} \mathrm{kg}^{-1}\right)$ & 11.1 & 0.24 \\
Exchangeable K $\left(\mathrm{cmol} \mathrm{kg}^{-1}\right)$ & 0.15 & 5.9 \\
Exchangeable Ca $\left(\mathrm{cmol} \mathrm{kg}^{-1}\right)$ & 1.81 & 1.8 \\
Exchangeable $\mathrm{Mg}\left(\mathrm{cmol} \mathrm{kg}^{-1}\right)$ & 0.40 & 3.8 \\
\hline
\end{tabular}

nd $=$ not determined 
methods, and MCA levels is shown in Table 2. When studied as an individual factor, Tillage methods (T) and MCA levels influenced soil physical properties (bulk, porosity, and moisture content) significantly. Effect of year (Y) on soil physical properties was not significant. Plowing plus harrowing $(\mathrm{P}+\mathrm{H})$ had lower bulk density, higher porosity, and lower moisture content compared with zero tillage (ZT) and manual ridging (MR). The order of reducing bulk density and moisture content and increasing porosity was $\mathrm{ZT}>\mathrm{MR}>\mathrm{P}+\mathrm{H}$. Maize cob ash reduced bulk density and increased porosity and moisture content from $0-6 \mathrm{t} \mathrm{ha}^{-1}$ in both years. In 2014, compared with the initial status of the soil before experimentation, application of $6 \mathrm{tha}^{-1} \mathrm{MCA}$ reduced the bulk density of ZT, $\mathrm{MR}$, and $\mathrm{P}+\mathrm{H}$ soil by $6.8,13$, and $19.2 \%$ respectively. In 2015 , the reduction was by $11.0,17.1$, and $24 \%$, respectively. The interactive effect of $\mathrm{Y} \times \mathrm{T}, \mathrm{Y} \times \mathrm{MCA}$ and $\mathrm{Y} \times \mathrm{T} \times \mathrm{MCA}$ were not significant. However, $\mathrm{T} \times \mathrm{MCA}$ was significant.

Data containing the effect of soil chemical properties on year tillage methods and MCA levels are shown in Table 3. Year, tillage methods and MCA influenced soil chemical properties significantly, however, year $(\mathrm{Y})$ did not influence
$\mathrm{pH}, \mathrm{OM}, \mathrm{N}$, and $\mathrm{P}$ significantly. The order of soil chemical properties among tillage methods was $\mathrm{P}+\mathrm{H}<\mathrm{MR}<\mathrm{ZT}$. The values of $\mathrm{pH}$ and $\mathrm{OM}$ were not significant for tillage methods. Maize cob ash increased all soil chemical properties $(\mathrm{pH}, \mathrm{P}$, $\mathrm{K}, \mathrm{Ca}$, and $\mathrm{Mg}$ ) considered significantly except $\mathrm{N}$ and $\mathrm{OM}$. The increase in soil $\mathrm{pH}$ and $\mathrm{OM}$ using MCA was from 0-6 $\mathrm{t}$ $\mathrm{ha}^{-1}$ while the increase was only up to $3 \mathrm{tha}^{-1} \mathrm{MCA}$ for $\mathrm{K}, \mathrm{Ca}$ and $\mathrm{Mg}$. Although, $3 \mathrm{t} \mathrm{ha}^{-1}$ ash had the highest values of $\mathrm{N}$ in both years, there were no significant differences between 0 , 3 and $6 \mathrm{t} \mathrm{ha}^{-1} \mathrm{MCA}$. The interactive effect of $\mathrm{Y} \times \mathrm{T}$ and $\mathrm{Y} \times$ $\mathrm{T} \times \mathrm{MCA}$ were not significant. That of $\mathrm{Y} \times \mathrm{MCA}$ was only significant for $\mathrm{K}, \mathrm{Ca}$, and $\mathrm{Mg}$ and not for $\mathrm{pH}, \mathrm{OM}, \mathrm{N}$ and $\mathrm{P}$. Also $\mathrm{T} \times \mathrm{MCA}$ was significant only for $\mathrm{N}, \mathrm{P}, \mathrm{K}, \mathrm{Ca}, \mathrm{Mg}$, and $\mathrm{pH}$ and not for OM.

\section{Response on okra yield}

Data containing the effect of okra yield and growth on year, tillage methods, and MCA levels are shown in Table 4. When studied as individual factors, tillage method $(\mathrm{T})$ and MCA influenced yield and growth of okra significantly. Year (Y) did not have influence on okra yield and growth

Table 2. Effect of year, tillage methods, and maize cob ash on soil physical properties.

\begin{tabular}{|c|c|c|c|c|c|}
\hline Year & Tillage method & $\begin{array}{c}\text { Maize cob ash level } \\
\left(\mathrm{t} \mathrm{ha}^{-1}\right)\end{array}$ & $\begin{array}{l}\text { Bulk density } \\
\left(\mathrm{Mg} \mathrm{m}^{-3}\right)\end{array}$ & $\begin{array}{c}\text { Total porosity } \\
(\%)\end{array}$ & $\begin{array}{c}\text { Moisture content } \\
(\%)\end{array}$ \\
\hline \multirow[t]{9}{*}{2014} & ZT & 0.0 & 1.46 & 44.9 & 16.2 \\
\hline & & 3.0 & 1.40 & 47.2 & 17.8 \\
\hline & & 6.0 & 1.36 & 48.7 & 19.5 \\
\hline & MR & 0.0 & 1.37 & 48.3 & 13.4 \\
\hline & & 3.0 & 1.30 & 50.9 & 15.3 \\
\hline & & 6.0 & 1.27 & 52.1 & 17.1 \\
\hline & $\mathrm{P}+\mathrm{H}$ & 0.0 & 1.26 & 52.5 & 12.1 \\
\hline & & 3.0 & 1.21 & 54.3 & 13.6 \\
\hline & & 6.0 & 1.18 & 55.5 & 15.3 \\
\hline \multirow[t]{9}{*}{2015} & $\mathrm{ZT}$ & 0.0 & 1.54 & 41.9 & 14.4 \\
\hline & & 3.0 & 1.34 & 49.4 & 18.7 \\
\hline & & 6.0 & 1.30 & 50.9 & 20.6 \\
\hline & MR & 0.0 & 1.42 & 46.4 & 11.6 \\
\hline & & 3.0 & 1.25 & 52.8 & 16.8 \\
\hline & & 6.0 & 1.21 & 54.3 & 18.6 \\
\hline & $\mathrm{P}+\mathrm{H}$ & 0.0 & 1.34 & 49.4 & 10.3 \\
\hline & & 3.0 & 1.15 & 56.6 & 14.9 \\
\hline & & 6.0 & 1.11 & 58.1 & 16.8 \\
\hline Year $(Y)$ & & & ns & ns & ns \\
\hline Tillage (T) & & & $*$ & $*$ & * \\
\hline Maize cob ash (MCA) & & & * & * & * \\
\hline$Y \times T$ & & & ns & ns & ns \\
\hline $\mathrm{Y} \times \mathrm{MCA}$ & & & ns & ns & ns \\
\hline $\mathrm{T} \times \mathrm{MCA}$ & & & $*$ & * & * \\
\hline $\mathrm{Y} \times \mathrm{T} \times \mathrm{MCA}$ & & & ns & ns & ns \\
\hline
\end{tabular}

Note: ${ }^{*}$ Significant difference at $P=0.05 ; \mathrm{ns}$, not significant at 0.05 . ZT, zero tillage; MR, manual ridging; $\mathrm{P}+\mathrm{H}$, plowing plus harrowing. 
Table 3. Effect of year, tillage methods, and maize cob ash on soil chemical properties.

\begin{tabular}{|c|c|c|c|c|c|c|c|c|c|}
\hline Year & $\begin{array}{l}\text { Tillage } \\
\text { method }\end{array}$ & $\begin{array}{c}\text { Maize cob } \\
\text { ash level } \\
\left(\mathrm{t} \mathrm{ha}^{-1}\right)\end{array}$ & $\begin{array}{c}\mathrm{pH} \\
\text { (water) }\end{array}$ & $\begin{array}{c}\text { Organic } \\
\text { matter }(\%)\end{array}$ & $\begin{array}{c}\text { Total N } \\
(\%)\end{array}$ & $\begin{array}{l}\text { Available } P \\
\left(\mathrm{mg} \mathrm{kg}^{-1}\right)\end{array}$ & $\begin{array}{l}\text { Exchangeable } \mathrm{K} \\
\left(\mathrm{cmol} \mathrm{kg}^{-1}\right)\end{array}$ & $\begin{array}{l}\text { Exchangeable } \mathrm{Ca} \\
\left(\mathrm{cmol} \mathrm{kg}^{-1}\right)\end{array}$ & $\begin{array}{l}\text { Exchangeable Mg } \\
\quad\left(\mathrm{cmol} \mathrm{kg}^{-1}\right)\end{array}$ \\
\hline \multirow[t]{9}{*}{2014} & $\overline{Z T}$ & 0.0 & 5.51 & 2.76 & 0.18 & 10.2 & 0.14 & 1.7 & 0.37 \\
\hline & & 3.0 & 6.89 & 2.90 & 0.19 & 12.5 & 0.38 & 2.9 & 0.42 \\
\hline & & 6.0 & 6.95 & 3.10 & 0.19 & 13.7 & 0.34 & 2.5 & 0.41 \\
\hline & $\mathrm{MR}$ & 0.0 & 5.48 & 2.46 & 0.16 & 9.8 & 0.13 & 1.5 & 0.34 \\
\hline & & 3.0 & 6.84 & 2.61 & 0.17 & 10.6 & 0.28 & 2.5 & 0.40 \\
\hline & & 6.0 & 6.91 & 2.79 & 0.17 & 12.1 & 0.24 & 2.5 & 0.40 \\
\hline & $\mathrm{P}+\mathrm{H}$ & 0.0 & 5.40 & 2.23 & 0.16 & 8.9 & 0.11 & 1.3 & 0.30 \\
\hline & & 3.0 & 6.82 & 2.46 & 0.17 & 9.5 & 0.20 & 2.2 & 0.36 \\
\hline & & 6.0 & 6.91 & 2.66 & 0.17 & 10.7 & 0.19 & 2.2 & 0.35 \\
\hline \multirow[t]{9}{*}{2015} & $\mathrm{ZT}$ & 0.0 & 5.49 & 2.71 & 0.17 & 10.1 & 0.14 & 1.5 & 0.35 \\
\hline & & 3.0 & 7.10 & 2.96 & 0.18 & 13.8 & 0.40 & 3.6 & 0.48 \\
\hline & & 6.0 & 7.40 & 3.20 & 0.18 & 14.7 & 0.40 & 3.5 & 0.47 \\
\hline & MR & 0.0 & 5.40 & 2.34 & 0.16 & 9.7 & 0.12 & 1.4 & 0.32 \\
\hline & & 3.0 & 7.05 & 2.78 & 0.16 & 11.9 & 0.30 & 3.1 & 0.40 \\
\hline & & 6.0 & 7.15 & 2.89 & 0.17 & 12.4 & 0.30 & 3.0 & 0.38 \\
\hline & $\mathrm{P}+\mathrm{H}$ & 0.0 & 5.38 & 2.18 & 0.16 & 8.4 & 0.09 & 1.2 & 0.28 \\
\hline & & 3.0 & 6.91 & 2.65 & 0.17 & 10.2 & 0.26 & 2.8 & 0.38 \\
\hline & & 6.0 & 7.01 & 2.77 & 0.17 & 12.3 & 0.21 & 2.7 & 0.37 \\
\hline Year (Y) & & & ns & ns & ns & ns & * & * & * \\
\hline Tillage (T) & & & ns & ns & * & * & * & * & * \\
\hline Maize cob ash (MCA) & & & * & ns & ns & * & * & * & * \\
\hline$Y \times T$ & & & ns & ns & ns & ns & ns & ns & ns \\
\hline $\mathrm{Y} \times \mathrm{MCA}$ & & & ns & ns & ns & ns & ns & * & * \\
\hline $\mathrm{T} \times \mathrm{MCA}$ & & & $*$ & ns & $*$ & * & * & * & * \\
\hline $\mathrm{Y} \times \mathrm{T} \times \mathrm{MCA}$ & & & ns & ns & ns & ns & ns & ns & ns \\
\hline
\end{tabular}

Note: ${ }^{*}$ Significant difference at $P=0.05$; ns, not significant at 0.05 . ZT, zero tillage; MR, manual ridging; $\mathrm{P}+\mathrm{H}$, plowing plus harrowing.

Table 4. Effect of year, tillage methods, and maize cob ash on yield and growth of okra.

\begin{tabular}{|c|c|c|c|c|c|}
\hline Year & Tillage method & $\begin{array}{l}\text { Maize cob ash level } \\
\underset{\left(\mathrm{t} \mathrm{ha}^{-1}\right)}{ }\end{array}$ & $\begin{array}{l}\text { Fruit yield } \\
\left(\mathrm{t} \mathrm{ha}^{-1}\right)\end{array}$ & $\begin{array}{l}\text { Plant height } \\
\text { (m) }\end{array}$ & $\begin{array}{l}\text { Leaf area/plant } \\
\left(\mathrm{m}^{2}\right)\end{array}$ \\
\hline \multirow[t]{9}{*}{2014} & $\overline{Z T}$ & 0.0 & 6.9 & 0.39 & 0.66 \\
\hline & & 3.0 & 7.6 & 0.45 & 0.71 \\
\hline & & 6.0 & 7.4 & 0.44 & 0.69 \\
\hline & MR & 0.0 & 7.9 & 0.43 & 0.75 \\
\hline & & 3.0 & 8.6 & 0.49 & 0.79 \\
\hline & & 6.0 & 8.5 & 0.46 & 0.76 \\
\hline & $\mathrm{P}+\mathrm{H}$ & 0.0 & 8.8 & 0.51 & 0.84 \\
\hline & & 3.0 & 9.9 & 0.55 & 0.89 \\
\hline & & 6.0 & 9.6 & 0.51 & 0.81 \\
\hline \multirow[t]{9}{*}{2015} & ZT & 0.0 & 6.5 & 0.33 & 0.61 \\
\hline & & 3.0 & 7.9 & 0.54 & 0.78 \\
\hline & & 6.0 & 7.6 & 0.52 & 0.76 \\
\hline & MR & 0.0 & 7.1 & 0.39 & 0.69 \\
\hline & & 3.0 & 8.9 & 0.59 & 0.86 \\
\hline & & 6.0 & 8.7 & 0.55 & 0.80 \\
\hline & $\mathrm{P}+\mathrm{H}$ & 0.0 & 8.2 & 0.46 & 0.77 \\
\hline & & 3.0 & 10.6 & 0.67 & 0.96 \\
\hline & & 6.0 & 9.8 & 0.65 & 0.94 \\
\hline Year (Y) & & & ns & ns & ns \\
\hline Tillage (T) & & & * & * & $*$ \\
\hline Maize cob ash (MCA) & & & * & * & * \\
\hline$Y \times T$ & & & ns & ns & ns \\
\hline$Y \times M C A$ & & & ns & ns & ns \\
\hline $\mathrm{T} \times \mathrm{MCA}$ & & & * & * & * \\
\hline $\mathrm{Y} \times \mathrm{T} \times \mathrm{MCA}$ & & & ns & ns & ns \\
\hline
\end{tabular}


Table 5. Effect of year, tillage methods, and maize cob ash on mineral and vitamin C compositions of okra fruits.

\begin{tabular}{|c|c|c|c|c|c|c|c|c|}
\hline Year & $\begin{array}{l}\text { Tillage } \\
\text { method }\end{array}$ & $\begin{array}{l}\text { Maize cob ash } \\
\text { level }\left(\mathrm{t} \mathrm{ha}^{-1}\right)\end{array}$ & $\mathrm{K}(\%)$ & $\mathrm{Ca}(\%)$ & $\operatorname{Mg}(\%)$ & $\mathrm{Cu}(\%)$ & $\mathrm{Fe}(\%)$ & $\begin{array}{l}\text { Vitamin C } \\
\left(\mathrm{mg} 100^{-1} \mathrm{~g}\right)\end{array}$ \\
\hline \multirow[t]{9}{*}{2014} & $\mathrm{ZT}$ & 0.0 & 112.1 & 144.8 & 135.4 & 0.61 & 14.1 & 11.6 \\
\hline & & 3.0 & 144.7 & 178.4 & 163.6 & 0.69 & 15.9 & 13.8 \\
\hline & & 6.0 & 143.6 & 174.3 & 161.8 & 0.64 & 15.4 & 13.7 \\
\hline & MR & 0.0 & 134.6 & 156.1 & 148.6 & 0.68 & 16.6 & 12.8 \\
\hline & & 3.0 & 154.1 & 189.1 & 177.1 & 0.75 & 17.8 & 14.9 \\
\hline & & 6.0 & 150.4 & 180.0 & 177.0 & 0.71 & 17.5 & 14.6 \\
\hline & $\mathrm{P}+\mathrm{H}$ & 0.0 & 146.0 & 171.8 & 168.3 & 0.79 & 18.8 & 13.6 \\
\hline & & 3.0 & 178.3 & 195.1 & 186.8 & 0.88 & 20.1 & 17.5 \\
\hline & & 6.0 & 168.4 & 194.3 & 184.1 & 0.88 & 20.1 & 17.3 \\
\hline \multirow[t]{9}{*}{2015} & $\mathrm{ZT}$ & 0.0 & 107.3 & 127.1 & 121.8 & 0.55 & 13.0 & 10.1 \\
\hline & & 3.0 & 157.4 & 189.6 & 172.4 & 0.78 & 16.5 & 14.8 \\
\hline & & 6.0 & 150.8 & 187.1 & 170.3 & 0.77 & 16.4 & 14.5 \\
\hline & MR & 0.0 & 119.6 & 138.2 & 130.1 & 0.65 & 14.6 & 11.1 \\
\hline & & 3.0 & 174.3 & 205.7 & 188.4 & 0.85 & 18.4 & 17.5 \\
\hline & & 6.0 & 170.2 & 201.5 & 184.1 & 0.84 & 18.2 & 17.2 \\
\hline & $\mathrm{P}+\mathrm{H}$ & 0.0 & 131.5 & 161.4 & 158.6 & 0.71 & 17.1 & 12.5 \\
\hline & & 3.0 & 190.4 & 250.7 & 279.6 & 0.98 & 23.4 & 18.8 \\
\hline & & 6.0 & 185.6 & 245.2 & 270.3 & 0.96 & 23.1 & 18.1 \\
\hline Year (Y) & & & * & * & * & * & ns & ns \\
\hline Tillage (T) & & & * & * & * & * & * & * \\
\hline Maize cob ash (MCA) & & & * & * & * & * & * & * \\
\hline$Y \times T$ & & & ns & ns & ns & ns & ns & ns \\
\hline $\mathrm{Y} \times \mathrm{MCA}$ & & & $*$ & * & * & * & ns & ns \\
\hline $\mathrm{T} \times \mathrm{MCA}$ & & & $*$ & * & $*$ & * & $*$ & * \\
\hline $\mathrm{Y} \times \mathrm{T} \times \mathrm{MCA}$ & & & ns & ns & ns & ns & ns & ns \\
\hline
\end{tabular}

significantly. Tillage influenced the yield and growth of okra in increasing order: $\mathrm{ZT}<\mathrm{MR}<\mathrm{P}+\mathrm{H}$. Maize cob ash in both years influenced okra yield and growth up to $3 \mathrm{t} \mathrm{ha}^{-1}$ level after which there was a decrease at $6 \mathrm{tha}^{-1}$ level. The optimum yield and growth was attained with $\mathrm{P}+\mathrm{H}$ at $3 \mathrm{t} \mathrm{ha}^{-1} \mathrm{MCA}$. Compared with the control, application of MCA at $3 \mathrm{t} \mathrm{ha}^{-1}$ increased fruit yield of okra for ZT, MR, and $\mathrm{P}+\mathrm{H}$ soils by 7.2, 8.9 and 12.5 in 2014 and 21.5, 25.4, and 29.3, respectively, in 2015. The interactive effect of $\mathrm{Y} \times \mathrm{T}, \mathrm{Y} \times$ $\mathrm{MCA}$, and $\mathrm{Y} \times \mathrm{T} \times \mathrm{MC}$ A were not significant. $\mathrm{T} \times \mathrm{MCA}$ was significant.

\section{Response on okra quality}

Data on the effect of okra fruit mineral and vitamin $\mathrm{C}$ contents on year, tillage methods, and MCA levels are presented in Table 5. As individual factor year (Y), tillage methods (T), and MCA influenced okra mineral and vitamin $\mathrm{C}$ contents significantly. $\mathrm{Y}$ did not influence $\mathrm{Fe}$ and vitamin $\mathrm{C}$ significantly. Year 2015 had higher values of $\mathrm{K}, \mathrm{Ca}, \mathrm{Mg}$, and $\mathrm{Cu}$ compared with year 2014. Among tillage methods, $\mathrm{P}+\mathrm{H}$ had the highest values of $\mathrm{K}, \mathrm{Ca}, \mathrm{Mg}, \mathrm{Cu} \mathrm{Fe}$, and Vitamin $\mathrm{C}$. the optimum values of $\mathrm{K}, \mathrm{Ca}, \mathrm{Mg}, \mathrm{Cu} \mathrm{Fe}$, and Vitamin $\mathrm{C}$ was attained at MCA applied at $3 \mathrm{t} \mathrm{ha}^{-1}$ in both years. The interactive effect of $\mathrm{Y} \times \mathrm{T}$ and $\mathrm{Y} \times \mathrm{T} \times \mathrm{MCA}$ were not significant. $\mathrm{Y} \times \mathrm{MCA}$ and $\mathrm{T} \times \mathrm{MCA}$ were significant. $\mathrm{Y} \times$ MCA was not significant for $\mathrm{Fe}$ and vitamin $\mathrm{C}$.

\section{Discussion}

Results (Table 1) show that the site was low in OM, N, K, $\mathrm{Ca}$, acidic with high bulk density. These conditions are the characteristics of Alfisols of southwest Nigeria (deRidder and Vankeulen 1990; Lal 1986). The fairly high bulk density before the start of the experiment was attributed to the low organic matter of the site (Obi and Nnabude 1995). The lower bulk density of $\mathrm{P}+\mathrm{H}$ and $\mathrm{MR}$ compared with $\mathrm{ZT}$ was due to the loosening effects of tillage. The low bulk density of $\mathrm{P}+\mathrm{H}$ compared with $\mathrm{MR}$ could be attributed to better pulverization of the soil by plowing and harrowing. The high bulk density of $\mathrm{ZT}$ compared with $\mathrm{MR}$ and $\mathrm{P}+\mathrm{H}$ could be due to non-tillage or compaction (Adekiya and Ojeniyi 2002; Hulugalle et al. 1985). $\mathrm{P}+\mathrm{H}$ with less bulk density had higher values of total porosity. This observation confirmed the inverse relationship between bulk density and total porosity. ZT had higher moisture content compared with $\mathrm{MR}$ and $\mathrm{P}+\mathrm{H}$. This could be related to organic matter in the soil surface which acted as mulch to reduce evaporation loss of water. The higher moisture content of ZT could also be related to their density, attendant lower porosity, and evaporation rate. Ojeniyi (1981) had earlier found that for sandy soils of southwest Nigeria, moisture content increased with bulk density. Hence, ZT soils with high bulk density value recorded relatively high moisture content.

MCA reduced bulk density and increased porosity of the 
soil. The increase porosity could be related to the porous nature of the ash. MCA reduced bulk density because porosity of ash is high and when applied to soil it significantly decease bulk density by increasing the pore volume. The reduction in bulk density and increased porosity as result of MCA could also be related to increased SOM and Ca. Both substances are cementing and stabilizing agents in soil aggregation. Improved aggregation leads to increase in porosity and reduction in bulk density. Ogbodo and Nnabude (2012) found that ash derived from burnt rice husks ameliorated unfavorable soil physical conditions in rice soil at Abakaliki, southeast Nigeria by reducing soil bulk density, increasing porosity, and infiltration rate. Similarly, Lal et al. (1996), Matte and Kene (1995), Miller (1999), and Dhindsa et al. (2016) also found that fly ash amendment to soils decreased bulk density. The increase in moisture content of the soil as a result of ash application was adduced to the soil having more micropores for physically retaining water. It can also be attributed to increased OM from the MCA which improved aggregation that created pore spaces resulting from greater earthworm burrowing and hence improve moisture. The interaction of $\mathrm{T} \times \mathrm{MCA}$ was significant, signifying the combinations of tillage and MCA in improving soil physical properties. Tillage in combination with MCA reduced soil bulk density, increased porosity, and moisture content. It obliterated effect of high soil bulk density and lower porosity associated with zero tillage.

In both years, soil chemical properties tend to be in the increasing order of $\mathrm{P}+\mathrm{H}<\mathrm{MR}<\mathrm{ZT}$. The higher nutrient contents of ZT compared with other tillage methods could be due to the presence of vegetative surface mulch which reduced leaching and increased activities of beneficial soil fauna in organic matter decomposition (Ojeniyi and Adekayode 1999). The lower values of soil chemical properties due to $\mathrm{P}+\mathrm{H}$ can be adduced to leaching, increased biological activities, and oxidation. The higher nutrient content of MR compared with $\mathrm{P}+\mathrm{H}$ could be due to minimal disturbance of soil in MR compared with $\mathrm{P}+\mathrm{H}$ during land preparation.

The result that $\mathrm{MCA}$ increased soil $\mathrm{pH}, \mathrm{P}, \mathrm{K}, \mathrm{Ca}$, and $\mathrm{Mg}$ contents can be due to the low initial soil fertility status of the site before experimentation. It also consistent with the analysis recorded for MCA (Table 1) and also the use of ash as soil amendment (Agbede and Adekiya 2012; Ezekiel et al. 2009; Ojeniyi et al. 2002; Owolabi et al. 2005). The increase in $\mathrm{pH}$ as a result of MCA is consistent with the fact that MCA being a Ca-containing mineral raised soil $\mathrm{pH}$. This confirmed that MCA improved the base status of the soil to which it is applied. The result that optimum soil chemical properties (N. P, K, Ca, and $\mathrm{Mg}$ ) was attained at $3 \mathrm{t} \mathrm{ha}^{-1}$ MCA can be adduced to the fact that $3 \mathrm{t} \mathrm{ha}^{-1}$ MCA was amount required for soil in the study area or similar soils elsewhere to significantly improve soil deficient in N, P, K, $\mathrm{Ca}$, and $\mathrm{Mg}$. The significant effect of $\mathrm{K}, \mathrm{Ca}$, and $\mathrm{Mg}$ in 2015 compared with 2014 was due to the residual effect of the ash in the second year due to accumulation from the first year.

In both years, $\mathrm{P}+\mathrm{H}$ produced the highest values of okra fruit yield, plant height and leaf area compared with MR and ZT. This can be adduced to its lower bulk density and higher porosity. The higher bulk density produced by other tillage methods especially ZT could cause mechanical impedance to root and this would adversely affect nutrient and water uptake, hence reduced yield and growth of okra. From this study, a degree of tillage appears to be indispensable for sustainable okra production on Alfisol of southwest Nigeria.

The addition of MCA to the soil significantly increased the yield and growth of okra. This is because ash is reported to increase soil nutrients (Nweke et al. 2016; Owolabi et al. 2005) and improved soil physical properties (Ogbodo and Nnabude 2012) compared with the control. Reduction of bulk density due to MCA would have increased nutrient and water uptake compared with no application. The result that irrespective of tillage methods, $3 \mathrm{t} \mathrm{ha}^{-1}$ MCA produced the optimum yield and growth of okra implies that the amount is just sufficient for okra production. Application of MCA up to $6 \mathrm{tha}^{-1}$ would be at the luxury level and contribute less to yield. The interactive effect $\mathrm{T} \times \mathrm{MCA}$ was significant for okra yield and growth. This could be due to positive cumulative relationship between tillage and MCA which further enhanced or fortified their improvement in soil physical and chemical properties. Combination of $\mathrm{P}+\mathrm{H}$ and $3 \mathrm{tha}^{-1} \mathrm{MCA}$ produced better yield and growth of okra compared with other combinations. This can be adduced to reduced bulk density of $\mathrm{P}+\mathrm{H}$ and optimum soil chemical properties produced by $3 \mathrm{t}$ $\mathrm{ha}^{-1}$ MCA.

The result was that okra mineral compositions were significantly increased in 2015 compared with 2014 is consistent with the soil chemical properties of these elements in the soil. It also shows the residual effects of these elements in the second year of application of MCA. The fact that tillage methods influenced mineral and vitamin $\mathrm{C}$ contents of okra fruit was due to the physical and chemical properties of the soil. The better performance of $\mathrm{P}+\mathrm{H}$ compared with other tillage methods in term of mineral composition can be adduced to lower bulk density and high porosity of $\mathrm{P}+\mathrm{H}$ which gave it better assess to nutrient in the soil compared with other tillage methods. Wozniak (2016) found that triticale grain from conventional tillage plots contains more starch, $\mathrm{Mg}$, $\mathrm{Mn}$, and Fe than grains from reduced tillage and no-tillage systems. The significant influence of MCA on mineral and vitamin $\mathrm{C}$ composition of okra indicated that MCA contains some nutrients which are released in the soil upon mineralization. MCA increased soil nutrient such as N, P, K, Ca, $\mathrm{Mg}$, and $\mathrm{pH}$ which are essential for improved mineral and vitamin C composition of okra.

The multiple regression of growth and yield component using soil chemical and physical properties (Table 6) shows that growth and yield of okra in this study was dependent on soil physical properties and chemical properties such as $\mathrm{pH}$, $\mathrm{OM}, \mathrm{N}$, and $\mathrm{K}$. This finding is as a result of degree of soil pulverization and the ease of root penetration to absorb the mineral in the soil. Trouse (1979) indicated that soil compressed just above $0.15 \mathrm{Mg} \mathrm{m}^{-3}$ could reduce root growth to 
Table 6. Effect of multiple regressions of growth and yield component using soil chemical and physical properties.

\begin{tabular}{|c|c|c|c|}
\hline $\begin{array}{l}\text { Growth and yield } \\
\text { component }\end{array}$ & $\mathrm{R}^{2 *}$ & Soil properties & $p$-value \\
\hline Yield & 0.990 & $\begin{array}{l}\mathrm{pH}, \mathrm{OM}, \mathrm{N}, \mathrm{P}, \mathrm{K}, \mathrm{Ca}, \mathrm{Mg}, \\
\text { BD, Porosity, MC }\end{array}$ & $\begin{array}{l}>0.042,>0.003,>0.006,>0.079,>0.001,>0.007,>0.768,>0.021,>0.025 \\
>0.000\end{array}$ \\
\hline Plant height & 0.990 & $\begin{array}{l}\mathrm{pH}, \mathrm{OM}, \mathrm{N}, \mathrm{P}, \mathrm{K}, \mathrm{Ca}, \mathrm{Mg} \\
\text { BD, Porosity, MC }\end{array}$ & $\begin{array}{l}>0.049,>0.047,>0.000,>0.133,>0.502,>0.077,>0.981 \\
>0.032,>0.000,>0.000\end{array}$ \\
\hline Leaf area & 0.994 & $\begin{array}{l}\mathrm{pH}, \mathrm{OM}, \mathrm{N}, \mathrm{P}, \mathrm{K}, \mathrm{Ca}, \mathrm{Mg} \\
\text { BD, Porosity, MC }\end{array}$ & $\begin{array}{l}>0.006,>0.047,>0.000,>0.168,>0.016,>0.535,>0.004,>0.035,>0.002, \\
>0.000\end{array}$ \\
\hline
\end{tabular}

about half of its capacity, such reductions in root growth could prevent nutrient and mineral absorption. Adekiya et al. (2017) showed that $\mathrm{N}$ and $\mathrm{K}$ are the most important macronutrient required for growth and okra yield. Furthermore, the high percentage of $\mathrm{Ca}$ in MCA (Table 1) should have enabled it to serve as a liming material for the control of acidity considering its high $\mathrm{pH}$. The limitation of the test soil is acidity which is known to reduce uptake and availability of nutrients important to okra (Adekiya et al. 2017; Brady and Weil 1999). It was reported that the optimum $\mathrm{pH}$ for okra is 6.5 (Simmone et al. 2004).

\section{Conclusion}

Tillage methods and MCA influenced soil physical and chemical properties, yield, growth, and mineral and vitamin $\mathrm{C}$ contents of okra fruit significantly. Year did not influence soil physical properties, $\mathrm{pH}, \mathrm{OM}, \mathrm{N}, \mathrm{P}$, yield, and growth of okra significantly, but did influence soil $\mathrm{K}, \mathrm{Ca}, \mathrm{Mg}$ and $\mathrm{K}$, $\mathrm{Ca}, \mathrm{Mg}$ and $\mathrm{Cu}$ contents of okra fruit. Maize cob ash in both years influenced soil $\mathrm{K}, \mathrm{Ca}, \mathrm{Mg}$, okra yield, growth, mineral and vitamin $\mathrm{C}$ contents of okra fruits up to $3 \mathrm{tha}^{-1}$ level after which there was a decrease at $6 \mathrm{tha}^{-1}$ level. From this study, a degree of tillage appears to be indispensable for sustainable okra production on Alfisol of southwest Nigeria. Growth and yield of okra in this study was dependent on soil physical properties (bulk density, porosity and moisture content) and chemical properties such as $\mathrm{pH}, \mathrm{OM}, \mathrm{N}$, and $\mathrm{K}$. Although, combination of $\mathrm{P}+\mathrm{H}$ and $3 \mathrm{tha}^{-1} \mathrm{MCA}$ produced better yield, growth, mineral and vitamin $\mathrm{C}$ contents of okra compared with other combinations of tillage with MCA, addition of MCA to $\mathrm{P}+\mathrm{H}$ or $\mathrm{MR}$ is important to reduce the limitation of acidity associated with tropical Alfisol.

\section{References}

Abdulhamid NA, Mustapha S. 2009. Influence of agricultural wood ash on some physico-chemical properties of sandy loam soils at Maiduguri, Nigeria. Journal of League of Researchers in Nigeria. 10 (1): 84-88

Adekiya AO, Agbede TM, Aboyeji CM, Dunsin O, Ugbe JO. 2017. Green manures and NPK fertilizer effects on soil properties, growth, yield, mineral and vitamin $\mathrm{C}$ composition of okra (Abelmoschus esculentus (L.) Moench). J. Saudi Soc. Agric. Sci. http://dx.doi.org/10.1016/j.jssas.2017.05.005

Adekiya AO, Agbede TM, Ojeniyi SO. 2016. The effect of three years of tillage and poultry manure application on soil and plant nutrient composition, growth and yield of cocoyam. Exp. Agric. 52 (3): 466- 476

Adekiya AO, Ojeniyi SO. 2002. Evaluation of tomato growth and soil properties under methods of seedling bed preparation in an Alfisol in the rainforest zone of southwest Nigeria. Soil Till. Res. 64: 275-279

Adekiya AO, Ojeniyi SO, Agbede TM. 2011. Soil physical and chemical properties and cocoyam yield under different tillage systems in tropical Alfisol. Exp. Agric. 47 (3): 477-488

Adekiya AO, Aboyeji CM, Dunsin O, Adebiyi OV, Oyinlola OT. 2018. Effect of urea fertilizer and maize cob ash on soil chemical properties, growth, yield, and mineral composition of okra, (Abelmoschus esculentus (L) Moench). J. Hort. Res. 26(1): 67-76.

Agbede TM. 2013. Effect of tillage and oil palm bunch ash plus poultry manure on soil chemical properties, growth and ginger yield. World Academy of Science, Engineering and Technology. Int. J. Agric. Biosys. Eng. 7(7): 481-488

Agbede TM, Adekiya AO. 2012. Effect of wood ash, poultry manure and NPK-15-15 15 fertilizer on soil and leaf nutrient composition, growth and yield of okra (Abelmoschus esculentum) on a degraded Alfisol of south west Nigeria. Emir. J. Food Agric. 24 (4): 314-321

Akinrinde EA, Obigbesan GO. 2000. Evaluation of the fertility status of selected soils for crop production in five ecological zones of Nigeria. In: O Babalola, ed, Proceedings of the $26^{\text {th }}$ Annual Conference of Soil Science Society of Nigeria; 2000 Oct 30-Nov 3; Ibadan, Nigeria; p. 279-288

AOAC. 2003. Official methods of analysis of the Association of Official Analytical Chemists International. 17th ed. Gaithersburg (MD): AOAC International

Brady NC, Weil RR. 1999. The Nature and Properties of Soils. Prentice-Hall, Upper Saddle River, New Jersey

Bremner JM. 1996. Nitrogen-total. In Methods of Soil Analysis. Chemical Methods, Part 3. 2nd edn, 1085-1121. DL Sparks, ed, SSSA Book Series No. 5, ASA and SSSA: Madison, WI, USA

Calisir S, Yildiz MU. 2005. A study on some physico-chemical properties of Turkeyokra (Hibiscus esculenta) seeds. J. Food Eng. 68: 73-78 
Carter MR. 1993. Soil sampling and methods of analysis. Canadian Society of Soil Science. Boca Raton (FL): Lewis; $p$. 823

deRidder N, van Keulen H. 1990. Some aspects of the role of organic matter in sustainable intensified arable farming system in west African semi- arid tropics. Fert. Res. 26: 29-31

Dhindsa HS, Sharma RD, Kumar R. 2016. Role of fly ash in improving soil physical properties and yield of wheat (Triticum aestivum). Agric. Sci. Digest. 36 (2): 97-101

Ewulo BS, Babadele OO, Ojeniyi SO. 2009. Sawdust ash and urea effects on soil and plant nutrient contents and yield of tomato. Amer.-Eur. J. Sust. Agric. 3(1): 88-92

Ezekiel PO, Ojeniyi SO, Asawalam DO, Ano AO. 2009. Root growth dry root yield and NPK content of cassava as influenced by oil palm bunch ash on Ultisols of southeast Nigeria. Niger. J. Soil Sci. 19(1): 6-10

FAO. 1994. Soil management for sustainable agriculture and environmental protection in the tropics. Rome, $33 \mathrm{pp}$

FAO. 1998. World Reference Base of Soil Resources. World Soil Resources Report 84. Foods and Agriculture Organization of the United Nations, Rome

Frank K, Beegle D, Denning J. 1998. Phosphorus. In: Brown JR, editor. Recommended chemical soil test procedures for the North Central Region, North Central Regional Research Publication No. 221 (revised). Columbia (MO): Missouri Agric. Exp. Station; p. 21-26

Gemede HF, Ratta N, Haki GD, Woldegiorgis AZ, Beyene F. 2014. Nutritional quality and health benefits of okra (Abelmoschus esculentus): a review. Food Sci. Qual. Manage. 33: 87-96

GENSTAT. 2005. Genstat 8th ed. Release 8.1. VSN International Ltd. Oxford, UK

Hendershot WH, Lalande H, Duquette M. 2007. Ion exchange and exchangeable cations. Soil sampling and methods of analysis. In: MR Carter, EG Gregorich, eds, Canadian Society of Soil Science. 2nd ed. Boca Raton (Florida): CRC Press; 197-206. Chapter 18

Horwitz W, Latimer GW. (Eds.), 2005. Official Methods of Analysis of the Association of Official Analytical Chemists International. Sixteenth ed. AOAC International, Gaithersburg, MD

Hulugalle NR, Lal R, Opara-Nadi OA. 1985. Effect of tillage system and mulch on soil properties and growth of yam (Dioscorea rotundata) and cocoyam (Xanthosoma sagittifolium) on an Ultisol. J. Root Crops 11: 9-12

Lal R. 1986. Soil surface management in the tropics for intensive land use and high and sustainable production. Adv. Soil Sci. 5: $1-104$

Lal JK, Mishra B, Sarkar AK, Lal S. 1996. Effect of fly ash on growth and nutrition of soybean. J. Ind. Soc. Soil Sci. 44: 310-313

Matte DB, Kene DR. 1995. Effect of fly ash application on yield performance of kharif and rabi crops. J. Soils Crops, 5: 133-136

Mihretu Y, Wayessa G, Adugna D. 2014. Multivariate Analysis among Okra (Abelmoschus esculentus (L.) Moench) Collection in South Western Ethiopia. J. Plant Sci. 9(2): 43-50
Miller E. 1999. Changes in the properties of sandy soil fertilized with different doses of ashes from "Dolna Odra" PowerStation, Florida University of Agricultural Research Station, 78, 189-202

Naveed A, Khan AA, Khan IA. 2009. Generation mean analysis of water stress tolerance in okra (Abelmoschus esculentus L.). Pak. J. Bot. 41: 195-205

Ndunguru J, Rajabu AC. 2004 Effect of okra mosaic virus disease on the above-ground morphological yield components of okra in Tanzania. Sci. Hort. 99: 225-235

Nweke IA, Mbah CN, Okoli PSO. 2016. Tillage methods and wood ash effect on soil properties and yield of castor. Greener J. Agric. Sci. 6(11): 331-341

Obi ME, Nnabude PC. 1995. The effect of different management practices on the physical properties of a sandy loam soil in southern Nigeria. Soil Till. Res. 12: 81-90

Ogbodo EN, Nnabude PA. 2012. Effect of tillage and crop residue on soil chemical properties and rice yield on an acid Ultisol at Abakaliki Southeastern Nigeria. Niger. J. Soil Sci. 22(1): 73-85

Ojeniyi SO.1981. Soil structure produced by tillage implements and their effects on soil water. Ghana J. Agric. Sci. 14: 45-49

Ojeniyi SO, Adekayode FO. 1999. Soil condition and cowpea and maize yield produced by tillage methods in the rainforest zone of Nigeria. Soil Till. Res. 51: 161-164

Ojeniyi SO, Oso OP, Arowotolu AA. 2002. Response of vegetables to wood ash Fertilizer. Proceeding 35th Annual Conference of Agricultural Society of Nigeria, UNAAB Abeokuta. p. 39-43

Omolaiye JA, Jayeoba OJ, Akoun J, Ogunbanjo OR, Adams BA, Ashidi JS. 2015. Development of leaf area prediction model of okra (Abelmoschus spp). Prod. Agric. Technol. 11 (1): 130-136

Owolabi O, Adeyeye A, Oladejo BT, Ojeniyi SO. 2003. Effect of wood ash on soil fertility and crop yield in Southwest Nigeria. Niger. J. Soil Sci.13: 55-60

Owolabi O, Ojeniyi SO, Amodu AO, Hazan K. 2005. Response of cowpea, Okra and tomato to sawdust ash manure. Moor J. Agric. Tes. 4(2): 178-182

Sheldrick B, Hand Wang C (1993): Particle-size distribution. In Soil Sampling and Methods of Analysis, MR Carter, ed., Canadian Society of Soil Science, Lewis Publishers, Ann Arbor, MI, USA. p. 499-511

Simmone EH, Hochmuth GJ, Maynard DN, Vavrina CS, Stall WM, Kucharek TA, Webb SE. 2004. Okra Production in Florida. Horticultural Sciences Department document HS729. Florida Cooperative Extension Service, Institute of Food and Agricultural Sciences, University of Florida

Singh J, Upadhyay AK, Prasad K, Bahadur A, Rai M. 2007. Variability of carotenes, vitamin $\mathrm{C}, \mathrm{E}$ and phenolics in Brassica vegetables. J. Food Comp. Anal. 20 (2): 106-112

Tel DA, Hagarty M. 1984. Soil and plant analysis. Study guide for agricultural laboratory directors and technologists working in tropical regions. In: Printed by International Institute of Tropical Agriculture (IITA) in conjunction with the University of Guelph. Guelph (Canada); p. 277 pp

Trouse AC Jr. 1979. Soil physical characteristics and root 
growth. In: R Lal, DJ Greenland, eds., Soil Physical Properties and Crop Production in the Tropics. John Wiley and Sons, Chichester, pp. 319-325

USDA 2010. Soil Taxonomy. 11th edn. Agriculture Handbook, No. 436, United States Department of Agriculture, Natural Resources Conservation Service: Washington DC

Varmudy V. 2011. Marketing Survey needed to boost okra exports. Department of economic Vive Kananda College, Puttur Karnataka

Woźniak A. 2016. Yield and chemical composition of spring triticale grain depending on cropping and tillage systems. Int. J. Plant Prod. 10(1): 45-52 